\title{
Review: Handbook of Contemporary Religions in Brazil
}

\author{
Leiden; Boston: Brill, 2016. Edited by Bettina E. Schmidt \\ and Steven Engler. ISBN-13: 978-9004321854. ISBN-10: \\ 9004321853, 552 p
}

\section{Antonio Genivaldo Cordeiro de Oliveira ${ }^{1}$}

Published online: 8 May 2017

(C) The Author(s) 2017. This article is an open access publication

The handbook intends to give a more complete overview of the Brazilian religious landscape with appropriate theoretical approaches given by several scholars who have devoted their research to the different expressions of the religious phenomena in that country. By contextualizing the Brazilian history and cultural diversity in the construction of the nation, the authors help to explain the varied and complex religious scenario that contrasts with the present almost completely monolingual country in spite of its extension.

In spite of the predominantly Christian background, there is a rich diversity within that matrix as well as distinct dynamics involved in the negotiation of the religious space, resulting from the interaction between different races and class distinct from other countries in America. This diverse scenario has undergone a quick change during the last decades. The editor's recognition of the distinct Brazilian features in the religious scenario prompted a different descriptive and conceptual approach beyond the European and North American ways of approaching religion. With this in mind, several authors who have an excellent knowledge of approaches given by Brazilian scholars and their literature that are not known by the public used to the English literature.

The book contextualizes also the study of religion within the Brazilian academic history. The studies of the religious phenomena in the country start with the advent of the social sciences. It is undeniable the European contribution, especially from France in the first period. The positivist heritage allied with growing Marxist influence in the 1960s onward has left religion almost ignored as a field of research in the Brazilian universities. That academic situation, reinforced by the military dictatorship that faced

Antonio Genivaldo Cordeiro de Oliveira

genoli73@gmail.com

1 Centro de Estudos de Religiões Alternativas, Pontifícia Universidade Católica de São Paulo, São Paulo, Brazil 
the Catholic Church's opposition, helps to see religion as something that really needed to be repressed. From the late 1970s, this situation started to change with the creation of the first programs on religious studies. From then on, several scholars have produced important studies, especially on syncretism, mestiçagem and hybridity. However, given a certain marginality to the Portuguese language, those studies have not achieved a broader audience. This is the first gap that this handbook intends to fill up.

The book has three parts: the first part, Religions in Brazil, deals with the religious traditions that shaped the 'Brazilian religious matrix' resulting from the encounter of the indigenous understanding of the spiritual world with the Iberian Catholicism and enriched by the African elements brought in by the black slave population. That matrix has found ways of accommodations that have resisted throughout the several political changes. However, the editors have made a choice of rescuing initially the indigenous expressions of the religiosity of the Guaraní religious understanding and mythology almost completely forgotten, except by the studies on ethnography. The vitality of these pre-Christian practices and the ways of understanding them through their mythology brought certain light to the contemporaneous expressions that always consider the encounter with nature as an encounter with the divinity. Several of those elements have survived and appear in different popular religious manifestations.

The introduction of new elements brought in by African slaves who also found their ways for the transmission and innovation of their religious traditions. These traditions had a complex hybridization process resulting in different expressions. The chapters dealing with these traditions are not limited to the mainstream tradition such as Candomble or Umbanda. Those traditions will especially mark the Brazilian Spiritism that has absorbed elements from those already hybridized traditions. Brazilian Kardecism that has become a large and thriving religion in the past decades and appears as an excellent example of the hybridity of the religious phenomena that took place in the country. Other minority religions such as Vale do Amanhecer and their allinclusiveness, and three other examples from the 'ayahuasca religions' help to illustrate that rich and hybrid scenario.

Traditional Protestantism is well presented in its three main waves. The first one is attached to the immigration phenomena. Featured by its opposition to local culture, it did not have an appeal to the mass population. The second wave was characterized by the arrival of different foreign missionaries that faced the initial hardships in the religious disputes in a market strongly marked by its catholic identity. With a 'brazilianization' of its leadership and boosted by the Pentecostal features, the third wave showed its ability to deal with local imaginary and cultural capital that has provoked a tremendous change in the past decades with the growth of evangelical churches. Several scholars pointed out that the increase of these churches is a result of their ability to dialogue and promote certain continuity with the cultural capital already established. In spite of the growth, the authors also highlight the decline in numbers in the past decades that have declared themselves as 'without religion'.

Besides these mainstream groups, other articles have giving attention to the Brazilian Jewish religion (marked by growing orthodox communities as a reaction to the secular society) and for those who claim their Jewish ancestry and their struggle to be recognized by the mainstream Judaism. Muslim communities face a significant increase in number of believers that are not Arabian migrants. This raises the question whether Islam in Brazil will become less Arabian and more Brazilian. Among the religious 
traditions brought to Brazil by migrants, there also appear Buddhism and Shintoism. However, in the past decades, new Japanese religions have been able to attract the audience of non-Asian Brazilians. Because of this, these religions have to face the challenge to maintain their connection with their roots while dialoguing with the deeply rooted Catholic identity. This part in the book finishes with an approach to the Hare Krishna communities as a sample of the New Religious Movements that have consolidated their space in Brazilian society.

The second part deals with the Brazilian Religions on the Diaspora. Several examples help to elucidate how Evangelical and Neo-Pentecostals Brazilian communities are organizing their ministry as well as supporting network for Brazilians in USA, Europe and Australia. There is the challenge of long-term sustainability and the need of more integration into the hosting society in order to attend the demands of the second generation. The need of adaptation in different contexts is well portrayed by the case of Santo Daime that in Europe it has been criminalized in several countries because of legal issues related to the use ayahuasca. Besides, that group has been challenged by the resistance of the new age audience because of the evident catholic elements present on their cults. This same challenge can be noticed in the John of God Movement in Australia. Local translators struggle to explain that in spite of using some catholic prayers and saints the practices of the religious leader is distinct from the Catholic Church, in order to gain audience expectations. The chapter dealing with Afro-Brazilian religions in Europe shows that these traditions have been exported and presented as a mark and cultural heritage of the 'brasilidade'. These sections show the fluidity, adaptability and malleability of Brazilian society and its effect on the religions exported from Brazil. At the same time, it brings excellent examples of the necessary dynamics of adaptation that religions are facing in order to fit into the different contexts of a globalized world.

Issues of Brazilian religions is the last part that shows the dynamics involving religion and politics, inequalities on gender and race, some understandings and conflicts arising from the dispute in the religious market. A remarkable article shows the specificities of secularism in the public sphere of the country where was not considered a foundational value in the Brazilian Republic. This results rather in a reciprocal instrumentalization between religion and politics throughout history, which until today has marked the latest presidential elections. Gender issues are considered demonstrating the high levels of women's participation that are not reflected in the leadership of several religious institutions. In the same line, another chapter challenges the supposed harmonious mixture of races and cultures that defended the idea of racial democracy. Another author deals with ritualistic purity and questions on syncretism raised by several Afro-Brazilian traditions that have gained awareness of their dignity and are striving to recover their lost ancestry. The section ends with an analysis of the open conflicts between the different religious traditions and churches in the dispute of adherents in the religious market. Competing for followers in the same socioeconomic group has resulted in certain 'battles' that involve the sacred symbols of different traditions. In spite of this competition, the ambiguity of the disputes also reveals the recognition of power in the different religious symbols that are going through a process of new resignification, produced recently in the Brazilian contemporary religious landscape. 
The book is an excellent instrument for scholars interested in the Brazilian religious scenarios and in the growing diversity of different religions in the large social religious market. It also is an excellent methodological instrument for those who wish to study religion as a concept that changes its meaning and significance in different contexts and to study as well the different approaches to religious phenomena that are not limited only to Europe and European scholarship.

Open Access This article is distributed under the terms of the Creative Commons Attribution 4.0 International License (http://creativecommons.org/licenses/by/4.0/), which permits unrestricted use, distribution, and reproduction in any medium, provided you give appropriate credit to the original author(s) and the source, provide a link to the Creative Commons license, and indicate if changes were made. 